\title{
Pengukuran level pembentukan es (ICING) pada pemodelan menggunakan rancang bangun sensor berbasis perubahan frekuensi dengan induktor datar
}

\author{
Yoga Dwi Cahyono, Samsul Hidayat*, Nugroho Adi Pramono \\ Universitas Negeri Malang, Jl. Semarang No. 5 Malang, Jawa Timur, Indonesia \\ *Penulis korespondensi, Surel: samsul.hidayat.fmipa@um.ac.id
}

Paper received: 01-08-2021; revised: 15-08-2021; accepted: 31-08-2021

\begin{abstract}
Icing is one of the main dangers for the flight and are cumulative. The icing is a process of accumulation of ice on parts of the aircraft, which will lead to changes in geometry and resulted in a variety of other disorders. For example, there was a buildup of ice on the propellor (propeller) and the engine carburetor so it can reduce the thrust plane even caused the plane to fall freely (stall). For it needs to be designed and built the Icing Detector as well as the actuator in providing early warning of the existence of the calculation and the icing on the pilot.
\end{abstract}

This instrument is designed with electronic units that use the oscillator as frequency generator and frequency meter based mikrokontroller ATmega8 as the measuring frequency. The surface of the sensor is made up of printed inductor with a broad surface for detection area. Sensors and electronic units connected by cable. In addition, modeling for the pilot indicators have been designed using the LCD.

Research results suggest that testing on "Ice Accretion-Level Measurement On Modelling using printed Inductor Sensor Prototype Based On Frequency Shifting" has been a successful made in accordance with the expected functions. These instruments can detect the occurrence of icing and give an indication of the thickness of the ice. It is possible to form a flat sensor installation on the aircraft to be more unobtrusive air flow, as well as a spacious surface produces more accurate results.

Keywords: Icing; Icing Detector; Printed Inductor; Osilator; ATmega8

\section{Pendahuluan}

Bidang kedirgantaraan khususnya di Indonesia kini dalam masa penelitian dan pengembangan. Dalam penerbangan sendiri, salah satu masalah yang dihadapi pesawat saat terbang adalah Icing. Icing adalah salah satu bahaya utama untuk penerbangan dan bersifat kumulatif. Icing menyebabkan banyak hal, diantaranya akumulasi es di sayap pesawat yang mengakibatkan bentuk sayap berubah, akumulasi es di propeler (baling-baling), akumulasi (blockage) es di pitot sistem (sistem untuk mendeteksi kecepatan pesawat), untuk pesawat dengan mesin piston terdapat bahaya lain jika terjadi Icing di karburator (Carburetor Icing), Es yang terbentuk di karburator akan menghambat aliran udara dan bahan bakar yang akan masuk ke silinder.

Kondisi kondisi tersebut mengurangi efisiensi pesawat dengan meningkatkan berat total, menghancurkan aliran udara pada sayap, mengurangi gaya angkat, penurunan gaya dorong, dan meningkatkan drag (gaya hambat). Icing juga mengganggu kinerja mesin pesawat. Efek icing lainnya termasuk kekeliruan indikasi pada instrumen penerbangan, kehilangan komunikasi radio, dan hilangnya operasi kontrol, rem, dan roda pendaratan. 
Statistik tahun 1990-2000 menunjukkan dari semua kecelakaan pesawat akibat cuaca, 12\% dari kecelakaan tersebut dikarenakan terjadinya Icing (sumber : AOPA Air Safety Foundation accident database).

Di wilayah Indonesia sendiri yang beriklim tropis, cuaca tidak terlalu ekstrim bagi kondisi icing sepertihalnya di negara negara beriklim subtropis dimana terdapat musim dingin dan cuaca bersalju, namun tidak menutup kemungkinan terjadinya icing. Pada peristiwa kecelakaan AirAsia QZ 8501, pusat penelitian dan pengembangan BMKG dengan analisis meteorologis (Errata) menyimpulkan bahwa berdasarkan data percakapan yang tersedia di lokasi terkahir pesawat yang diterima, cuaca adalah faktor pemicu terjadinya kecelakaan tersebut. Fenomena yang paling memungkinkan adalah terjadinya icing yang dapat menyebabkan mesin pesawat mengalami kerusakan karena pendinginan. (Prof. Edvin Aldrian, dkk ;Pusat Penelitian dan Pengembangan; data.bmkg.co.id)

Saat ini sensor untuk mendeteksi pembentukan es (icing) pada pesawat terbang kebanyakan menggunakan instrumen dengan sensor unit yang berbentuk stik probe yang terpasang bukan pada titik titik kritis terbentuknya es (terlalu mengganggu aliran udara jika pada sayap pesawat). Bahkan ada pula yang menuliskan kondisi icing hanya dapat diketahui oleh pilot dengan melihat kondisi pesawatnya.

Dari hal tersebut diatas ditambah dengan kondisi kekinian dari dunia kedirgantaraan khususnya di Indonesia, perlu untuk melakukan penelitian dan pengembangan tentang Icing, Icing Detector, Anti Icing, maupun Deicing nya. Namun dalam penelitian dan pengembangan kali ini, peneliti hanya akan mengangkat bahasan mengenai Icing dan bagaimana mengembangkan Sensor Icing serta Indikatornya (untuk pilot) guna memberikan perhitungan dan peringatan pada pilot.

\section{TEORI PENUNJANG}

1.1. Icing

Dalam penerbangan, kodisi icing merupakan kondisi dimana terbentuk es di permukaan badan pesawat, atau ketika karburator di dalam mesin pesawat membeku. Icing terjadi ketika uap air membeku di bawah titik beku. Fenomena ini tidak membahayakan penerbangan dengan seketika namun secara perlahan-lahan apabila kondisi ini dibiarkan terus-menerus.

Kondisi icing didefinisikan bisa terjadi pada suhu di bawah $10^{\circ} \mathrm{C}$ dan di atas $40^{\circ}$ dan terdapat visible moisture (uap air yang terlihat seperti kabut, awan dll). Jadi jika cuaca berkabut/ hujan/awan dan suhu berada di bawah $10^{\circ}$ C maka dimungkinkan terjadinya icing.

\subsection{Induktor Datar}

Induktor datar yang digunakan pada penelitian ini berupa koil datar melingkar yang dibuat menggunakan teknologi PCB (Printed Circuit Board). Prinsip fisika dari induktor datar adalah berdasar pada perubahan induktansi karena gangguan dari bahan konduktif. Arus AC yang dialirkan pada kumparan menghasilkan medan magnet dan membangkitkan arus eddy pada bahan konduktif yang menghasilkan induksi magnetik. Induktansi total antara koil datar dengan bahan konduktor 
merupakan fungsi jarak antara keduanya. (Djamal, 2010) Perubahan nilai induktansi total ini yang akan digunakan sebagai sensor pendeteksi ketebalan icing.

1.3. Osilator LC

Beberapa osilator gelombang sinus menggunakan rangkaian resonan yang terdiri atas induktansi dan kapasitansi. Osilator LC merupakan kelompok osilator balikan, dimana sebagian daya keluaran dikembalikan lagi pada masukan. Jaringan induktor-kapasitor (LC) pada rangkaian osilator digunakam sebagai penentu frekuensi keluaran. Jaringan LC sering disebut sebagai "rangkaian tangki" karena kemampuannya menampung tegangan AC pada frekuensi tertentu. Ketika rangkaian tangki digunakan untuk membangkitkan osilasi pada osilator, frekuensi keluaran dari osilator adalah frekuensi resonansi dari rangkaian tangki yang dapat ditentukan dengan menggunakan rumus :

$$
f_{r}=\frac{1}{2 \pi \sqrt{L C}}
$$

dimana fr adalah frekuensi resonansi dalam Hertz (Hz), L adalah induktansi dalam henry dan $\mathrm{C}$ adalah Kapasitansi dalam farad. Resonansi terjadi saat reaktansi kapasitif (Xc) besarnya sama dengan reaktansi induktif (XL). Rangkaian LC akan berosilasi pada frekuensi ini.

1.4. Permeabilitas Magnetik

Semua benda mempunyai sifat magnetik yang dapat terpengaruh oleh medan magnet. Efek yang ditimbulkan oleh medan magnet tersebut mungkin sangat lemah, tapi dapat diukur dengan mudah. Sifat magnetik yang paling umum dan mudah diukur adalah suseptibilitas.

Suseptibiltas magnetik suatu material mewakili kecenderungan suatu material untuk menjadi bahan magnet dalam pengaruh medan magnet luar. Pengukuran suseptibilitas memungkinkan kita untuk mengidentifikasi mineral pembawa Fe dalam suatu sampel, menghitung konsentrasi atau volume mineral tersebut, mengklasifikasi jenis-jenis mineral yang berbeda, serta mengidentifikasi proses pembentukan dan perpindahan mineral tersebut. (Dearing, 1999.op. Cit. Andreas, 2004). Suseptibilitas magnetik $\chi$ suatu bahan dapat diperoleh dari persamaan :

$$
M=\chi \cdot H
$$

Dengan $M$ adalah magnetisasi induksi (momen dipol magnet persatuan volume) $(\mathrm{A} / \mathrm{m})$ dan $\mathrm{H}$ adalah kuat medan magnetik yang diberikan $(\mathrm{A} / \mathrm{m})$.

Selain suseptibilitas, permeabilitas magnetik juga dipakai mendeskripsikan sifat kemagnetan bahan. Permeabilitas magnet pada dasarnya sama dengan suseptibilitas magnetik. Permeabilitas magnetik terhubung dengan suseptibilitas magnetik melalui persamaan :

$$
\mu_{r}=\chi+1
$$



relatif.

Dengan $\mu_{\mathrm{r}}$ adalah permeabilitas magnetik relatif, dan $\chi$ adalah suseptibilitas

\subsection{Mikrokontroller ATmega8}

Mikrokonroller ATMEGA8 Mikrokonroller adalah sebuah sistem mikroprosesor dimana didalamnya sudah terdapat CPU, ROM, RAM, I/O, Clock dan peralatan internal lain yang sudah terhubung dan terorganisasi dengan baik oleh pabrik pembuatnya dan dikemas dalam suatu chip yang siap pakai. Sehingga kita tinggal memprogram isi ROM sesuai aturan penggunaan oleh pabrik pembuatnya (Ardi Winoto, 2008).

1.6. LCD

LCD (Liquid Crystal Display) adalah sebuah alat yang berfungsi untuk menampilkan huruf, angka atau simbolsimbol tertentu. Dalam mikrokontroler LCD dipakai sebagai output dari mikrokontroler dan berguna sebagai interface antara user (manusia) dan alat. Tipe LCD yang sering digunakan adalah LCD $16 \times 2$ (16 kolom 2 baris) dan LCD 20 x 2 (20 kolom 2 baris).

Dalam pengoperasian LCD ada tiga buah line control, yaituline EN, line RS, dan line RW. Jika LCD dioperasikan sebagai mode 4 bit, maka diperlukan 7 buah line (3 line control dan 4 data bus). Sedangkan jika dioperasikan sebagai 8 mode bit diperlukan 11 buah line (3 line control dan 8 data bus). Operasi internal pada chip controller ditentukan oleh sinyal-sinyal yang diirim oleh unit mikroprosessor atau mikrokontroller.

\section{Metode}

Bentuk penelitian ini adalah reserach and development. Hal ini karena metode penelitian yang digunakan adalah sebagai prosedur untuk merancang dan mengembangkan suatu produk yang berkualitas. Metode yang digunakan adalah procedural, yaitu menggariskan langkah-langkah yang harus diikuti untuk menghasilkan suatu alat. Langkahlangkah tersebut adalah merumuskan potensi dari masalah, mengumpulkan informasi yang dapat digunakan sebagai bahan untuk perencanaan produk, mendesain produk awal, melakukan validasi desain produk, memperbaiki desain produk setelah melakukan validasi.

Dalam perancangan alat ini, setelah semua alat dan bahan disiapkan, set up perangkat keras dapat mulai dilakukan. Berikut adalah diagram dari perangkat keras dalam penelitian dan pengembangan ini :

\section{Gambar 1. Diagram perancangan alur kerja perangkat keras}

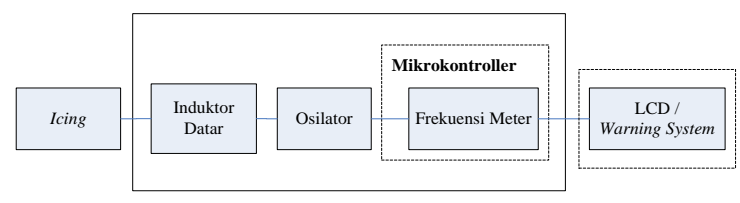




\section{Hasil dan Pembahasan}

Hasil dari penelitian ini menampilkan bentuk gelombang yang divisualisasikan dengan menggunakan osiloskop dan nilai frekuensi yang yang dihasilkan oleh osilator dengan menggunakan frequency meter Atmega8. Pengujian unit elektronik dengan sensor induktor datar dilakukan pada kondisi lingkungan sebagai berikut : Suhu Lingkungan 26,6 ${ }^{\circ} \mathrm{C}$, dan kelembaban $62,4 \%$.

\section{Gambar 2. Gelombang sinus uji osilator}

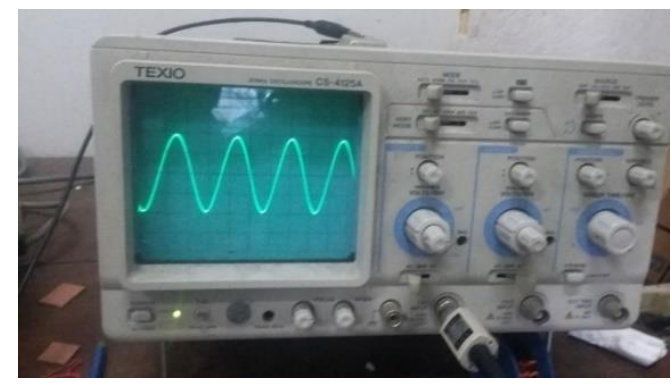

Gambar 3. Grafik Kestabilan Frekuensi Osilator tanpa Objek Sensor (Udara).

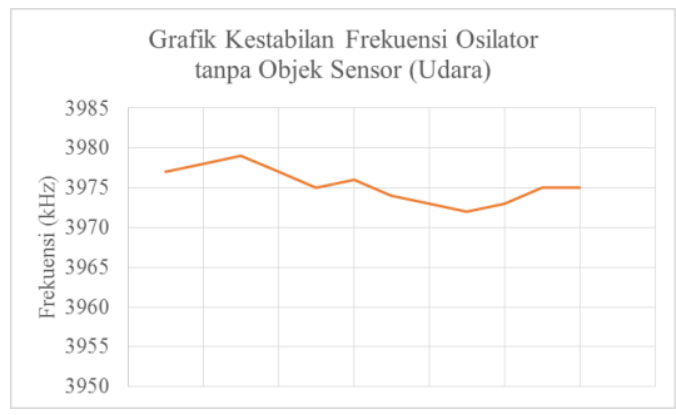

Gambar 3. Grafik Frekuensi (kHz) terhadap Perubahan Jarak Objek (Lembar PCB)

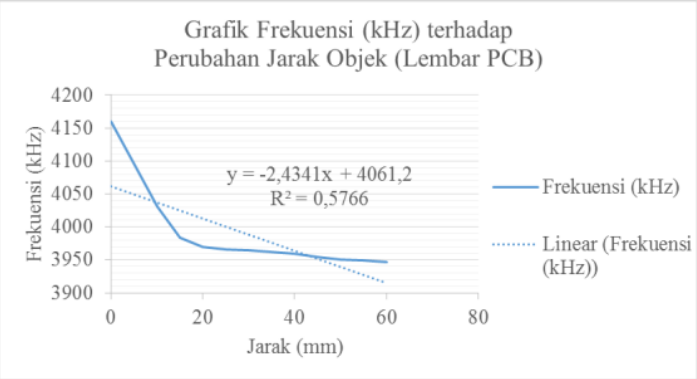

Gambar 3. Grafik Frekuensi (kHz) terhadap Ketebalan Es (mm)

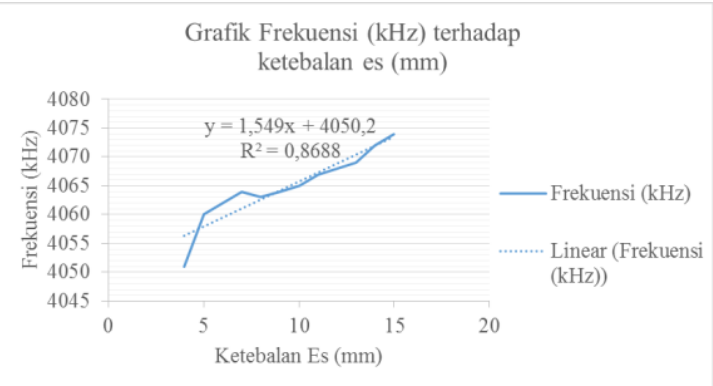




\section{Simpulan}

Pengujian pada "Pengukuran Level Pembentukan Es (Icing) Pada Pemodelan Menggunakan Rancang Bangun Sensor Berbasis Perubahan Frekuensi Dengan Induktor Datar" ini telah berhasil dibuat sesuai dengan fungsi yang diharapkan.

Instrumen ini dapat mendeteksi awal mula terjadinya icing dan memberikan indikasi frekuensi terhadap ketebalan es. Bentuk sensor yang datar dimungkinkan instalasi pada pesawat menjadi lebih tidak mengganggu aliran udara, serta permukaan yang luas menghasilkan hasil yang lebih akurat.

\section{Daftar Rujukan}

Atmel Corporation. (2013). 8-bit Atmel with 8KBytes InSystem Programmable Flash [Data set]. http://ww1.microchip.com/downloads/en/DeviceDoc/Atmel-2486-8-bit-AVRmicrocontrollerATmega8_L_datasheet.pdf

AOPA Air Safety Foundation. (2002). Aircraft Icing. Safety Advisor, Weather No.1. (Online), SA11, (http://flighttraining.aopa.org/pdfs/SA11_Aircraft_Icing.pdf)

Australian Goverment, Bureau Meteorology. (2011). Hazardous weather phenomena. Aircraft Icing. (Online), (www.bom.gov.au)

Civil Aviation Authority. (2000). Aircraft icing handbook. Version 1. (Online), (http://www.caa.govt.nz/safety_info/gaps/aircraft_icing_handbook.pdf)

Mook, G., Hesse, O., \& Uchanin, V. (2007). Deep penetrating eddy currents and probes. Materials Testing, 49(5), 258-264.

Purnama, I. (2011). Rancang Bangun Alat Pengukuran Laju Kendaraan Berbasis Mikrokontroler ATMEGA 8 (Doctoral dissertation, Universitas Komputer Indonesia).

Triana, F., Setijadi, E., \& Purnomo, M. A. (2008). Pengukuran dan Pemodelan Konstanta Dielektrik Air Hujan pada Frekuensi Gelombang Mikro. 